\title{
The National Bank of Romania monetary policy characteristics in addition to the current financial crisis
}

\author{
Ştefan Sâmbotin Ph.D, \\ Iulia Andreea Bucur Ph.D, \\ "Vasile Alecsandri" University of Bacău, Romania
}

\begin{abstract}
Considering the starting point for research the Central Bank key role in economic life, through the implementation of the monetary policy, by exercising prudential control and supervision of commercial banks, the present paper proposes an analysis of the National Bank of Romania monetary policy coordinates in the frame of the increased intensification harsh effects of the global economic crisis.
\end{abstract}

Keywords: $E 52, E 58, G 01$

global financial crisis, monetary policy instruments, financial stability, prudential indicators, inflation targeting, monetary policy interest rate, credit risk

\section{JEL Code:}

\section{Introduction}

Government intervention is carried out mainly by monetary and fiscal policy, because these policies are compatible with market economy laws and principles of democratic governance. Monetary policy meets an important role in preventing and managing financial crises, especially given that most central banks in the world have taken explicit price stability as primary objective, in the context of the globalization of markets, development of non-bank financial intermediation and financial innovation.

\section{The impact of the current financial crisis on the Romanian banking system}

The global economic and financial crisis strongly manifested in 2009 represented the dominant context deeply negative where Romanian real and financial sector operated. The current account external deficit adjustment has strongly impacted on the companies' performance, incomes of the economy and on the evolution of financial system, significantly increasing the vulnerability of the economic system.

The banking system, with comfortable levels of solvency and liquidity, has absorbed well the crisis shocks but with the cost of a lower performance, of growing risks of dynamics and persistence of non-performing loans, prolonged inhibition of loans demand and a relatively high dependency on external financing.

A stabilizing factor has been the funding agreement signed by authorities with European Union (EU) and International Monetary Fund (IMF). The prospects of banking system and, generally speaking, of national financial system mostly depend on economic system revival 
and regional developments. The main characteristics of Romanian banking system contain ${ }^{l}$ : 42 credit institutions (out of which 10 foreign bank branches and one credit cooperative); Assets: 78,19 billion euro (about 67\% from GDP); Top five banks own 52,4\% of the total assets; The solvency indicator: 14,03\%; The foreign shareholding owns the majority of banking capital. The biggest 9 banks with foreign capital (69\% of system assets) come from EU. The largest market share belongs to banks with Austrian capital $(38,1 \%)$ and the largest share in aggregate foreign capital belongs to the bank with Greek capital; Market share: $85,3 \%$ credit institutions with majority foreign capital; $7,2 \%$ credit institutions with majority domestic private capital; $7,5 \%$ credit institutions with majority state-owned domestic capital. In 2008 and in the first quarter of 2009 the structure of Romanian banking sector saw no significant changes. The trend of expansion of the activity in the territory and the rise in staff numbers was alleviated in the final part of the year in the context of global crisis. The moderate concentration continues its downward trend.

The licensing of a foreign capital bank, BCR Banca Pentru Locuinţe, the establishment of a new branch of DEPFA Bank Plc. Dublin, the discontinuing activity of Banca di Roma as a result of a merger, changes in a bank's shareholding of ABN AMRO Bank, currently RBS Bank România S.A., following its being taken over by Royal Bank of Scotland, did not alter the structure of the banking sector. Starting with January 2009, CitiBank România S.A. changed its bank status - from Romanian legal entity with foreign capital into the Romaniabased branch of Dublin-based CitiBank Europe.

At the end of 2008 on Romanian territory there were 43 credit institutions compared to 42 in late 2007 of which 32 are authorized by the National Bank of Romania (NBR) to operate as Romanian legal entities, 10 branches of EU banks in a credit cooperative network.

At the end of 2008, in Romania, there were 43 credit institutions compared to 42 at the end of 2007, out of which 32 were licensed by the NBR to operate as Romanian legal entities, 10 branches of EU banking groups and a credit cooperative network. At the end of March 2009, the number of credit institutions was unchanged, the only modification, at structure level, being the new status of CitiBank.

Actually the banking sector continued to report positive financial soundness indicators, displaying good capitalization and noticeable financial results. Stress testing analyses indicate a solid absorption capacity of moderate shocks. Two vulnerabilities are more prominent, being fuelled by the global economic and financial crisis: credit risk and liquidity risk.

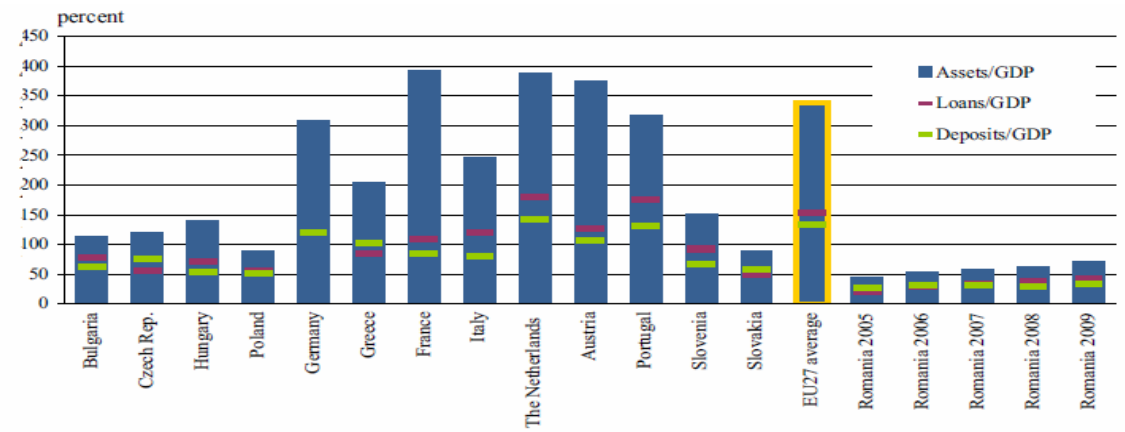

Figure 1. Financial intermediation in Romania and other Member States of EU Note: EU countries data used refer to 2008

Source: http://www.bnro.ro/Statistic-report-606.aspx

Starting with the latter part of 2008, the loan portfolio quality has seen a sharper deterioration, indicating particularly the slower economic activity and the weaker domestic currency. The deterioration is not even across banks, the largest ones posting higher levels of

\footnotetext{
${ }^{1}$ Popa R., Evoluţii recente ale indicatorilor de stabilitate financiară caracteristici sectorului bancar din Romania în contextul crizei globale, online version on http://www.bnro.ro
} 
overdue and doubtful loans. In spite of the faster worsening of loan portfolios of late, the quality of these portfolios overall is in line with the EU requirements. Also the coverage by provisions of non-performing loans in the balance sheets of credit institutions in Romania is higher than that reported by several EU Member States ${ }^{2}$.

As shown in Figure 1, the degree of financial intermediation remains below the European average and below the values recorded by other new EU member state.

In the context of the uncertainties as an effect of global crisis and risk aversion of banks, private lending sector has decreased in intensity in spite of monetary policy measures taken by Central Bank. As I said before, an increasing vulnerability of the Romanian banking system is the worsening quality of loans portfolio mainly in the context of economic recession and increasing unemployment, and also due to the high level of interest rates charged by the banks.

According to Figure 2, banks have enough own resources in order to cover the unexpected credit risk losses, remained uncovered by the provisions and the exploiting of collateral provided by the debtors.

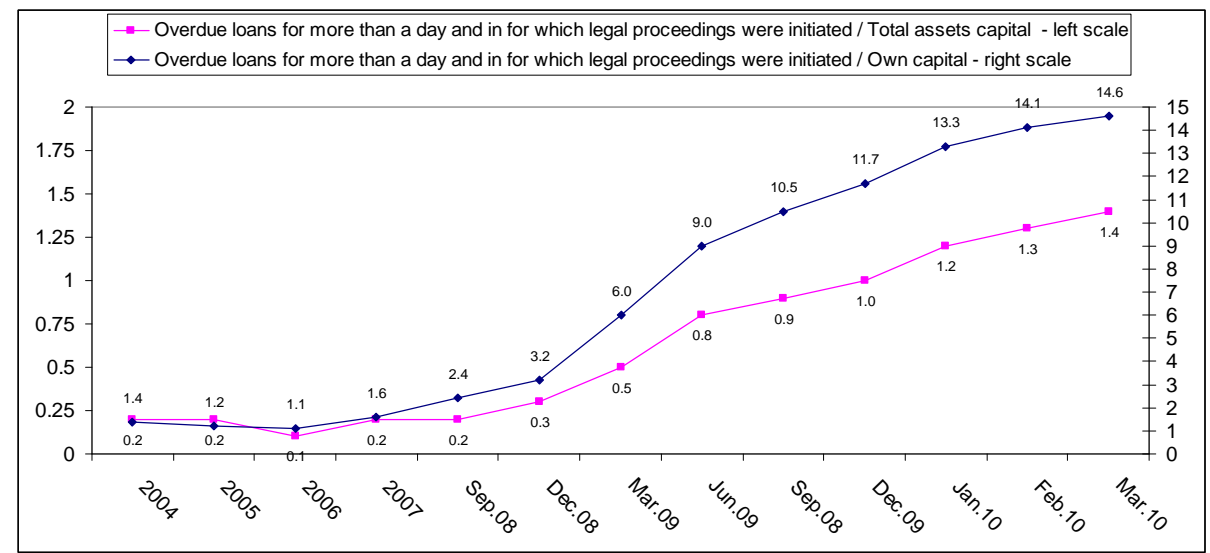

Figure 2. The evolution of loans portfolio between 2004 and 2010

Source: http://www.bnro.ro/statistic-87.aspx

The credit cost has significantly increased because of the worsening economic environment and because of difficulty to raise more rare and more expensive financial resources. The savings have increased in the context of positive interest rates of deposits.

The profitability of the banking system has been positive although banks' profit decreased. No bank from Romanian banking sector has not been in payment default during the year 2009. According to Figure 3, the net profit sharply decreased in 2009 compared to 2008, but at the beginning of 2009 recorded a slightly increase.

Prudential and profitability indicators in 2008, even its have slightly deteriorated compared to last year show that the Romanian banking system is strong. The new tighter lending conditions have reduced the Romanian appetite for lending, considering that the banks had to become more restrictive in lending, starting with customers' quality. Thus the lending of "subprime" it is avoided.

The banks need to resume lending when the economic fundamentals justify it, not when the "state" dictates. The business environment is still unstable and the banks cannot be put in a position of a philanthropist. Without real "guarantees" banking activity has no place. Rather, their exposure to high risks may deepen the economic crisis. The state must become a partner in the fight against the eradication of crisis, cooperation between governments, businesses, banks and central bank is indispensable.

\footnotetext{
${ }^{2}$ NBR (2009), Annual Report on Financial Stability, online versiun on www.bnro.ro
} 


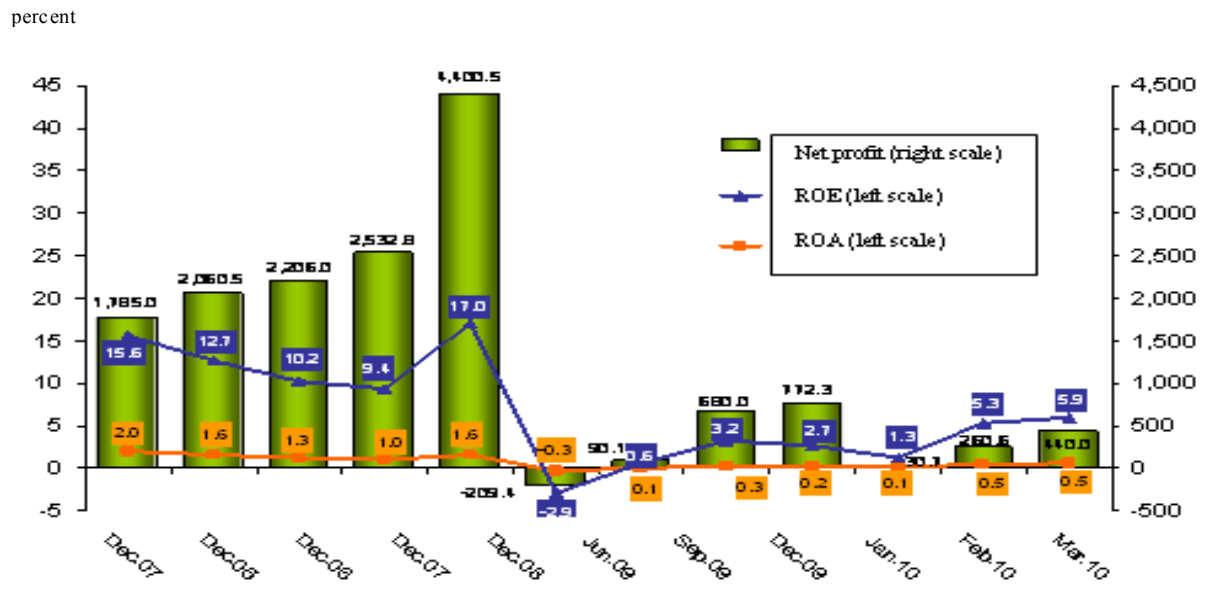

Figure 3. The evolution of banking system profitability between 2004 and 2010 Source: National Bank of Romania

The foreign exchange reserve is consistent, ready to be thrown into the market when it will be need it. The Romanian banks haven't invested so far in "toxic assets", especially on the European market. Romanian banks hold significant reserve requirements at central bank, recently $20 \%$ of deposits in RON (at this moment $18 \%$ ), and for those currency reserve rate is still $40 \%$. This demonstrates that the central bank has enough available cash to gradually pump in the system in case of liquidity crisis. However, there are some negative aspects regarding to the strength of the Romanian banking system ${ }^{3}$ :

$\checkmark$ about $57 \%$ of loans are granted in foreign currency, which makes the banks' portfolio sensitive to exchange rate fluctuations;

$\checkmark$ some macroeconomic indicators have worsening trends, which may cause instability in the external capital flows;

$\checkmark$ the international situation, especially developments in the foreign exchange markets from region make Romania vulnerable, especially in the speculative attacks;

$\checkmark$ the public is losing confidence in the banking system because of the unethical behavior of some banks, especially in this tense period (increasing interest rates and unreasonable fees);

$\checkmark \quad$ the existence of banking products with promotional interest and later variable which could affect the future repayment capacity of some customers;

$\checkmark$ because of the liquidity crisis abroad, some parent banks will pump less money in Romanian subsidiaries.

In conclusion, in the context of the lack of viable government's measures for economical recovery, the waves of layoffs in the budget and private environment will affect the banks' customers portfolio and will lead to a widening balance of non-performing loans and lower savings capacity. Consumer demand will drop and at the same time the loan demand.

\section{The adjustment of the NBR monetary policy instruments in the frame of the current financial crisis}

The effects of the international financial crisis have extended over Romanian economy. However, in terms of direct impact, the banking system was less affected because it was not

\footnotetext{
${ }^{3} \mathrm{http}: / /$ capraru.finantare.ro/tag/sistemul-bancar-romanesc/
} 
exposed to toxic assets, and because of prudential and administrative measures adopted over the time by the National Bank of Romania.

However, indirectly, the international financial crisis and especially its obvious consequence - the recession in developed countries - is expanding on the Romanian economy on multiple channels. On the commercial channel, the international financial crisis slows exports' growth or even reduces them. On the financial channel, it limits the access to external financing, and in this way it restricts the volume of lending, and it causes difficulties in the private external debt service.

On the exchange rate channel, the reducing of external financing has been reflected in national currency depreciation. On confidence channel, has been a withdrawal of investors from Eastern Europe. On the monetary and foreign exchange market, this caused some moments of panic and speculative attacks like the one in October in Romania, which has required the intervention of central bank. Finally, on the wealth and balance sheet effects' channel, there is a deterioration of the net assets of the households and companies because of a large share of loans in foreign currency (related with Romanian LEU's depreciation) and because of a fall in asset's prices of real estates and securities from speculative unsustainable values (type "bubble") 4 .

The propagation of these effects determines a high uncertainty regarding to the developments of economic variables. This helps to turn the crisis by emphasizing the negative effects it has on expectations and by increasing the degree of caution amongst consumers and businesses.

In Romania, the response to the adverse effects of the crisis cannot be similar to that made by some European countries or to the U.S. There are some differences between the Romanian economy and these economies, which do not allow copying the measures developed there. In essence, it's about the fact that the Romanian economy has a large current account deficit, which indicates its dependence on external financing. We have to choose between orderly reduction of the deficit or its reducing by the market in current conditions of tension and mistrust, with dramatic consequences for exchange rate and economic growth.

Generally speaking, signing several financing agreements with international institutions as the European Commission and European Investment Bank, in order to compensate the sensitive loss of private capital inflows is welcome. If all these steps will be followed, there is a high probability that the investors improve their perception concerning Romania and prefer to invest here more than in other Central or Eastern Europe countries. But the high probability is not equal with the certainty: we cannot exclude the scenario according to which although Romanian authorities do what need to be done the foreign investors would not positive react, and treat Romania unequal than its neighbors.

A danger for implementation of this coherent strategy orderly adjustment of external in balance is made of more and more gloomy forecasts developed by different institutions regarding economic growth of Romania and which anticipate a negative growth. The danger consists in the political factor having confidence in these forecasts could treat emotionally this problem, releasing unsightly fiscal and wage measures that could deepen the crisis ${ }^{5}$.

Even if it is obvious that several sectors that until 2008 were the motors of economic growth (real estate activities, financial banking activities, imports of automobiles, metallurgy industry, chemical industry, construction industry) will decrease in 2010, but there still are some sectors (IT, telecommunications, food products and pharmaceuticals, public services) that can develop and support a positive economic growth. In the same time it takes into account that an effort is necessary to rebuild consumer's confidence in the economy

\footnotetext{
${ }^{4}$ Isărescu M. (2009), România şi criza financiară internaţională, online version on http://www.bnro.ro

5 Isărescu M. (2009), Nouă lecţii din actuala criză financiară, online version on www.bnro.ro/Document Information.aspx
} 
evolution, confidence that was sharply decreased (like the consumer confidence index posted by EC) on the background of emotionally treatment of crisis ${ }^{6}$.

At the present the monetary policy strategy of NBR - inflation targeting - is closely connected with the current financial crisis and with the problems that our country has faced. The option for inflation targeting adoption as a monetary policy strategy it was justified by the necessity of achieving a sustainable disinflation. The implementation of inflation targeting strategy was not easy even before the financial crisis appearance and the fiscal dominance, massive capital inflows, NBR net debtor position towards the banking system and monetary policy transmission mechanism combined so that between 2005 and 2007 there were periods when inflation expectations and faster domestic currency appreciation coexisted. This raised a serious dilemma for central bank. Increasing interest rates in order to bring expectations at the same level with inflation target attracted more and more foreign capital that caused an unsustainable domestic currency appreciation.

At the same time with financial crisis in July 2007 a part of these conditions has disappeared. Today NBR tends to be net creditor for the banking system, and foreign capital inflows have diminished significantly. But this does not simplify the implementation of monetary policy. On the contrary, financial crisis increases the volatility on foreign exchange and monetary market and amplifies the slowdown the economical activity. On the one hand the drop of external financing and the existence of a large external imbalance caused domestic currency depreciation that fueling inflation and make necessary a relative high level of interest rate.

Moreover, the debtors with euro and other foreign currency debts and the entire financial system are vulnerable in front of a significant depreciation of domestic currency. On the other hand a higher interest rate would tend to slow down the economic growth and moreover would create costs for the debtors risking to destabilize the financial sector. In these conditions a delicate problem appears between the objectives of monetary policy: maintaining prices stability and ensuring financial stability. The efficiency of monetary policy for achieving this objective is limited if there is not financial stability. One of the basic macroeconomic principle says that the frictions on financial plan have an important influence on business cycle. Today on global plan this thing it is very obvious. World's central banks try to maintain financial stability and to avoid the economic recession and the depression.

Romanian experience shows that financial stability has a significant importance for price stability. Romania was criticized for disinflation delays. They were due to insufficient structural reforms. Our country has achieved an average rate of disinflation of 5.8 percentage points per year between 2000 and 2007, while maintaining financial system stability. But if NBR would be substituted this lack of reforms with a sharper increase of interest rate, the financial situation of companies and households had damaged. And thus the financial stability of banking system had damaged. Finally, even the disinflation pace had been, probably, lower than the pace achieved.

$N B R$ 's policy regarding foreign exchange intervention was guided by the philosophy that high exchange rate volatility is harmful for both the inflation objective and the financial health of the real and financial sector. As shown in Figure 4, current financial crisis has brought an abrupt reversal of the trend of domestic currency appreciation, with important episodes of volatility. As, in the past, foreign currency inflows overestimated domestic currency (Romanian LEU) well above the level indicated by the fundamental factors of the exchange rate, the reduction of external financing and uncertainty tend to cause the depreciation of the domestic currency undue to fundamental factors of the exchange rate. The reserves bought on foreign exchange market in times of over appreciation are good for intervenes in order to slow down the domestic currency depreciation.

\footnotetext{
${ }^{6}$ Isărescu M. (2009), Finanţarea dezechilibrului extern şi ajustarea macroeconomică în condiţiile crizei financiare. Cazul României, online version on http://www.bnro.ro/PublicationDocuments.aspx?icid=6885
} 


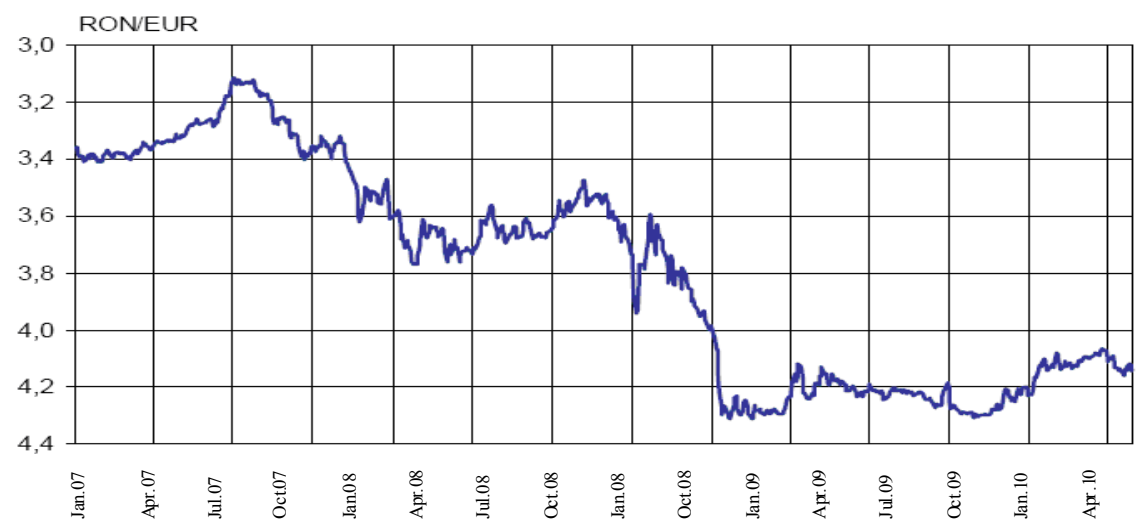

Figure 4. The evolution of exchange rate volatility between Jan. 2007 and Apr. 2010

Source: http://www.bnro.ro/datasets-628.aspx

During 2010, the NBR has decided to conduct interventions in the euro area public and private debt securities markets, under a securities markets program, to ensure depth and liquidity in those market segments that are dysfunctional. The objective of this program is to correct the malfunctioning of securities markets and to ensure the proper functioning of monetary policy transmission mechanism. In making this decision, it has taken note of the statement by the euro area government authorities that they "will take all the necessary measures needed to meet their fiscal targets for the current year and in the years ahead in line with excessive deficit procedure" and of the precise additional commitments made by some euro area government to accelerate fiscal consolidation and to ensure the sustainability of public finances. The impact of those interventions will be sterilized by conducting specific operations to reabsorb the liquidity injected through the securities markets program.

In addition, the central bank decided to adopt a fixed rate tender procedure with full allotment in regular refinancing operations with a maturity term of 3 months, which will be allocated in May and June. Finally, the central bank decided to reactivate, in cooperation with other central banks the temporary liquidity swap lines with the Federal Reserve System and to resume U.S. dollar liquidity providing operations at terms of 7 and 84 days. These operations will take the form of reversible operations in exchange for eligible collateral for European Central Bank (ECB) and will be carried out as fixed rate tenders with full allotment. The first of such operations was carried out on the $11^{\text {th }}$ of May, 2010.

National Bank of Romania considers that the above measures are essential to ensure the effectiveness of the monetary policy transmission mechanism. The measures will help to mitigate the spillover of increased financial market volatility, liquidity risk and market distortions in the access to finance in the economy. The sterilization of the interventions in the euro area public and private debt securities markets will ensure that the program for the securities markets does not affect the liquidity and interest rates levels from the money markets. Thus, the measures adopted do not affect the monetary policy stance ${ }^{7}$.

\section{Conclusions}

Effectiveness of National Bank of Romania monetary policy has registered a positive trend in recent years by speed and flexibility, as compared with fiscal policy whose implementation requires parliamentary deliberations, central bank interventions in the

\footnotetext{
${ }^{7}$ NBR (2010), Buletin lunar BCE - mai 2010, http://www.bnro.ro/Buletinul-lunar-BCE---mai-20105654.aspx
} 
banking market and the currency market experienced intensification with beneficial effects for fluctuation interest and exchange rates.

Since the new law the organization approved in 2004 (Law no. 312/2004 on the National Bank of Romania), the institutional, financial and operational central bank independence has been strengthened. However, the transparency of the institution has become more visible to the public and for professionals by publishing regular reports, newsletters and studies. However, the communication activity with business, academia and media, at central and local, have sufficient reserves to improve and increase, by explaining the objectives, instruments, transmission channels and the impact of monetary policy measures, especially in this period when economic and financial crisis requires drastic austerity measures.

Consistency, transparency and credibility of monetary and financial policies are critical to eliminate any confusion in the economic and financial environment.

\section{References}

1. Popa R., Evoluţii recente ale indicatorilor de stabilitate financiară caracteristici sectorului bancar din Romania in contextul crizei globale, http://www.bnro.ro

2. BNR (2009), Annual Report on Financial Stability, http://www.bnro.ro

3. http://capraru.finantare.ro/tag/sistemul-bancar-romanesc/

4. Isărescu M. (2009), România şi criza financiară internaţională, online version on http://www.bnro.ro

5. Isărescu M. (2009), Nouă lecţii din actuala criză financiară, online version on www.bnro.ro/Document Information.aspx

6. Isărescu M. (2009), Finanţarea dezechilibrului extern şi ajustarea macroeconomică în condiţiile crizei financiare. Cazul României, online version on http://www.bnro.ro/PublicationDocuments.aspx?icid=6885

7. NBR (2010), Buletin lunar BCE - mai 2010, online version on http://www.bnro.ro/Buletinullunar-BCE---mai-2010-5654.aspx 